\title{
Assessment of Biodiesel Fuel Potentials of Seed Crude Oil Extracts of Balanites aegyptiaaca (L.) Del
}

\section{${ }^{*}$ CHOMINI, MS; ${ }^{2}$ DASPAN, AJ; ${ }^{1} \mathrm{KAMBAI}, \mathrm{C} ;{ }^{2} \mathrm{CHOMINI}, \mathrm{AE} ;{ }^{3} \mathrm{BASSEY}, \mathrm{EA}$; ${ }^{4}$ FATOKE V; ${ }^{1}$ RABIU, AU}

\author{
${ }^{1}$ Department of Forestry Technology, Federal College of Forestry, Jos, Nigeria \\ ${ }^{2}$ Department of Science Laboratory Technology, Federal College of Forestry, Jos, Nigeria \\ ${ }^{3}$ Montane Forest Research Station, Jos, Nigeria \\ ${ }^{4}$ Department of Agricultural Technology, Federal College of Forestry, Jos, Nigeria \\ *Corresponding author: e-mail: stevemchoms@gmail.com, Tel: +2348030608552
}

\begin{abstract}
S: Study on assessmentof biodiesel fuel potentials of seed crude oil extracts of Balanites aegyptiaaca (L.) Del was carriedout. Standard methods of the Association of Official and Analytical Chemist (AOAC) were adopted to evaluate the proximate, physico-chemical properties and fatty acid compositions of crude seed oil extracts of the test plant. The proximate constituents of the crude seed oil extract gave crude protein $(22.09 \%)$, crude fat $(56.75 \%)$, moisturecontent $(1.35 \%)$, ash $(4.70 \%)$, crudefiber $(12.75 \%)$ and carbohydrate $(2.36 \%)$. The crude oil physicochemical properties included saponification value $(216.439 \mathrm{mgKOH} / \mathrm{g})$, peroxide value $(4.84 \mathrm{meq} / \mathrm{kg})$, acid value $(2.18 \mathrm{mgKOH} / \mathrm{g})$, iodine value $(77.08 \mathrm{~g} / 100 \mathrm{~g})$, viscosity value $\left(150.3 @ 30^{\circ} \mathrm{C}\right)$ and cetane number $(54.08)$, refractive index $\left(1.487 @ 30^{\circ} \mathrm{C}\right)$, relative density $\left(0.949 \mathrm{~g} / \mathrm{cm}^{3}\right)$ while calorific value was $39.03(\mathrm{MJ} / \mathrm{kg})$. The fatty acids composition of crude kernel oil extract of B. aegyptiaca indicated the presence of four (4) fatty acids, with relative percentage abundance (RPA) in the order of $67.17 \%\left(9,12\right.$-Octadecanoic acid $\left(\mathrm{C}_{19}\right.$ $\left.\left.\mathrm{H}_{34} \mathrm{O}_{2}\right)\right)>16.22 \%\left(\right.$ Pentadecanoic acid $\left.\left(\mathrm{C}_{17} \mathrm{H}_{34} \mathrm{O}_{2}\right)\right)>11.8 \mathrm{~kg} \%$ (Heptacosanoic acid $\left.\left(\mathrm{C}_{28} \mathrm{H}_{56} \mathrm{O}_{2}\right)\right)>4.72 \%$ (Oleic $\left.\operatorname{acid}\left(\mathrm{C}_{18} \mathrm{H}_{34} \mathrm{O}_{2}\right)\right)$. These properties conferred relative prospects on the crude oil of the test plant as a suitable potential biodiesel substrate and consequently, large scale aforestation efforts be renewed, to guarantee ready availability of the raw materials.
\end{abstract}

\section{DOI: https://dx.doi.org/10.4314/jasem.v24i8.24}

Copyright: Copyright $\mathbb{C} 2020$ Chomini et al. This is an open access article distributed under the Creative Commons Attribution License (CCL), which permits unrestricted use, distribution, and reproduction in any medium, provided the original work is properly cited.

Dates: Received: 06June 2020; Revised: 25 July 2020; Accepted: 10 August 2020

Keywords: Balanites aegyptiaca, Biodiesel, proximate, physicochemical, crude seed oil extracts

The fossil fuels namely coal, natural gas and oil, remain the predominant global energy consumed in the world today (Yunus and Zuru, 2017). These sources are finite, expecting to be exhausted in the near future. The utilization of the nonrenewable energy is powered by rising human population and industrialization. This enhancescarbon emissions, engenders environmental and human health concerns, as well as promoting ozone layer depletion and climate change (Banik et al., 2018). Consequent upon the aforementioned, attention is being directed to renewable energy resources in anticipation to the exhaustibility of fossil fuel reserves and the growing environmental concerns (Sreedhar and Yandapalli, 2016). Biodiesels are bio-based diesels, described as the best alternative fuels for diesel engines, are environmentally friendly, biodegradable, with higher energy efficiencies, and essentially non acidic (Igbumet al., 2012). Also known as methyl esters, they have higher cetane numbers $(\mathrm{CN})$ which is the measure of diesel quality, with other characteristics similar to fossil-based diesel fuels. Conventionally, biodiesel is produced by trans-esterification of triglyceride feedstock such as vegetable oil, animal fat and used cooking oil. The resulting triglyceride is treated with methanol or other short chain alcohols with a catalyst. Homogeneous base catalysts are mostly used in industrial biodiesel production because trans-esterification reaction proceeds with fast rate under mild reaction conditions. However, separation of the catalyst and purification of the products require large amount of water (Jain and Sharma, 2014). The use of edible vegetable oil seeds for biodiesel production is strongly discouraged, owing to the tendency for rising cost due to competition for these edible substrates.In this regard, it becomes imperative for cheap, inedible biomass that meet all criteria for consideration as useful alternative biodiesel feedstock(Umaru and Aberuagba, 2012). Such substrates include waste food oils, by products of vegetable oil refining, vegetable oils or animal fats etc. Different studies have reported attempts to evaluate 
the biodiesel potentials of oil - rich seeds. Umaru and Aberuagba, (2012), studied the characteristics of Jatropha curcas oil seeds for biodiesel production. Odjobo and Umaru (2019), investigated the biodiesel fuel potential of Canarium schweinfurthii Seed and Pulp Oils in order to determine the fuel quality parameters of the biodiesel produced. The potentials of Hura crepitans seed oil as an alternative feedstock for biodiesel fuel have also been evaluated (Adewuyi et al., 2014). The use of seed oil of Balanites aegyptiaca as biodiesel feedstock in Nigeria is still at the infancy, as paucity of literatures accounted for this (Jauro and Adams, 2011; Gutti et al., 2012). This study therefore investigated the biochemical, constituents of Balanites aegyptiaca seed oil as a potential feedstock for biodiesel production.

\section{MATERIALS AND METHODS}

The preliminary seed preparations and extractions was carried out in the chemistry laboratory of Federal College of Forestry, Jos. While analysis was done in National Research Institute for Chemical Technology (NARICT), Zaria Kaduna State, Nigeria.
Source of and Preparation of Seeds: The kernels of the test plant, Balanites aegyptiaca otherwise known as desert date, sourced from Toro - Bauchi State, were collected in sterilized polythene bags and identified in the Herbarium of the Federal College of Forestry, Jos (FCFJ), Plateau State, Nigeria.

Oil extraction: The modified methods of Ejilah et al. (2012), were adopted for the oil extraction processes. The nuts were air- dried in the chemistry lab, FCFJ, for 15 days. Dried nuts were sorted by removing damaged nuts which were believed to lower quality of oil (Sandulachi et al., 2019). One kilogram of the Nuts were mechanically decorticated to remove the kernels. The extracted kernels were further air-dried for 10 days. The kernels were weighed using weighing balance, pulverized using mortar and pestle followed by toasting at temperature between $45-47^{\circ} \mathrm{C}$, so as to reduce moisture and ease extraction (MLambo et al., 2011). The kernel oilwas extracted by traditional methods as described by Abu-Al-Futuh (1989), involving pouring of the pulverized toasted materials into hot water (floatation), followed by decantation and drying(Figure 1). The oil obtained was analyzed for proximate and some potential biodiesel properties.

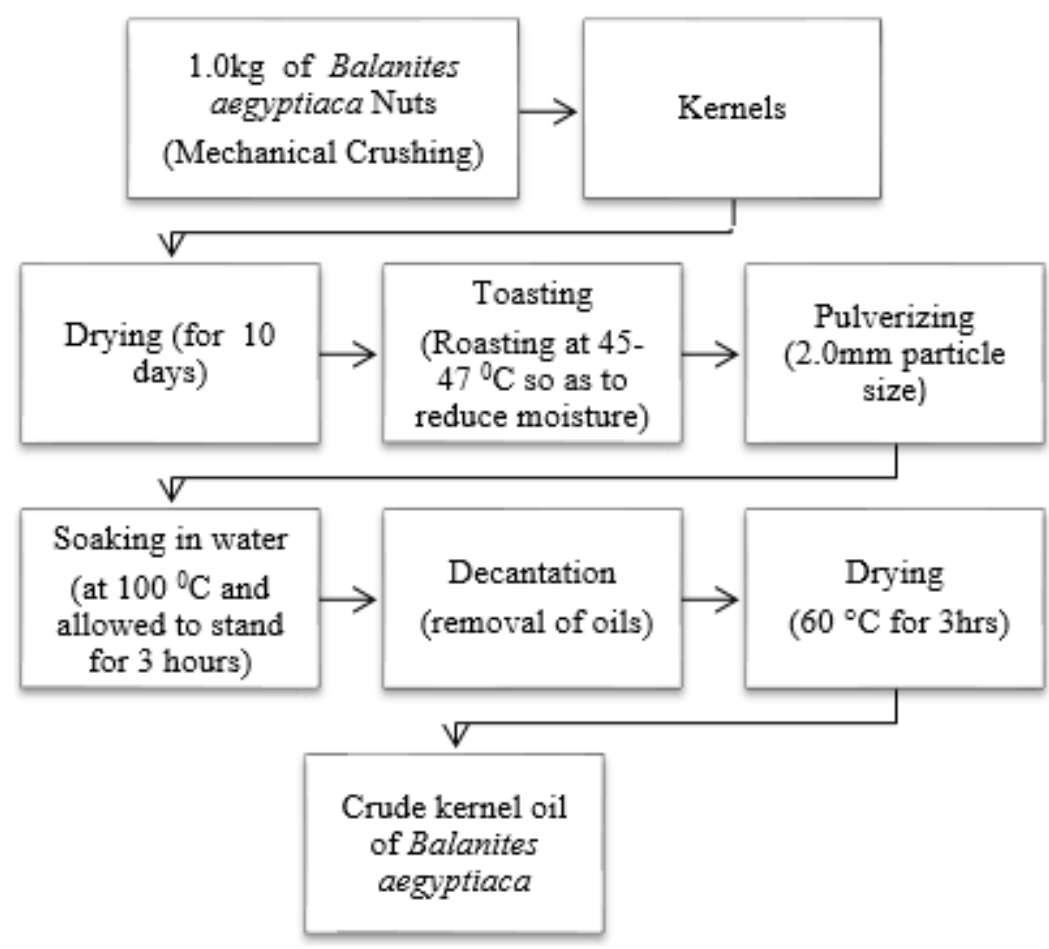

Fig 1: Flow chart of production Crude kernel oil of Balanitesaegyptiaca.

Nutritional composition Analysis: This was carried out based on standard methods of AOAC (1997) at the National Research Institute for Chemical Technology (NARICT), Basawa Zaria, Kaduna State, Nigeria
Physical and Chemical Potential Biodiesel Property: The biodiesel properties of extracted oil of Balanites aegyptiaca were done in accordance with the American Society of Testing Material (ASTM, 1993) 
methods. This to determine the kinetic, density viscosity (using Clandon Viscometer, model: VT-03 Viscometer), the specific gravity (using specific gravity bottle) as described Umaru and Aberuagba, (2012), saponification value, peroxide and iodine value (Pearson and Paraquit, 2006; Umaru and Aberuagba, 2012). The Acid value was tested by dissolving $2.0 \mathrm{~g}$ of each of the oil samples separately in $50 \mathrm{~cm} 3$ ofmixed neutral solvent $(25 \mathrm{~cm} 3$ dimethyl ether with $25 \mathrm{~cm} 3$ of ethanol carefully neutralized with $0.1 \mathrm{M}$ $\mathrm{NaOH}$, using $1 \%$ phenolphthalein solution). The mixture was titrated with $0.1 \mathrm{M} \mathrm{NaOH}$ aqueous solution with constant shaking to achieve a faint pink color (Umaru and Aberuagba, 2012).

Fatty acids composition: Gas chromatography and Mass Spectrometry (GC-MS) of model: QP2010 and HP5973 respectively, (NARICT), were used to determine the fatty acids composition of the oil sample of the B. aegyptiaca with as described by (Rizvi, 2009).

Some measurable quantities: The refractive index (1) determined using the Perkins mathematical formula reported by Babatunde and Bello (2016) (Eq. 1).

$$
\begin{gathered}
\mathrm{RI}=1.45765+0.0001164 \mathrm{IV} \\
\text { Where; RI }=\text { Refractive Index; IV }=\text { iodine value }
\end{gathered}
$$

The cetane number of the methyl esters content of the oil was calculated based on Krisnangkura (1986), as described by Adewuyi et al (2014), using the formula (Eq. 2) below

$$
\mathrm{CN}=46.3+\frac{5458}{S V}-(0.225 \times \mathrm{IV})
$$

Where SV = Saponification value; IV = iodine value

The calorific value was determined based on Batel et al (1980), as described by Adewuyi et al (2014), using the formula (Eq. 3) below

$$
\mathrm{CV}=47,643-4.187 \mathrm{I}-38.31 \mathrm{~S}(\mathrm{in} \mathrm{Kj} / \mathrm{kg})
$$

Where $\mathrm{I}=$ iodine value; $\mathrm{S}=$ Saponification value;

\section{RESULTS AND DISCUSSION}

The proximate composition analysis of the crude kernel oil of Balanites aegyptiaca gave $1.35 \%$ moisture, 4.70\% Ash, 56.75\% crude lipid, 22.09\% protein, $12.75 \%$ crude fibre and $2.6 \%$ carbohydrate (Figure 2). The relatively lower \% moisture content of Balanites aegyptiaca is an indication of a reasonable longer shelf life of Balanite oil over Canarium schweinfurthii (Adewale et al, 2009; Jauro and Adams, 2011). The high content of $\%$ ash, \%lipid and $\%$ crude protein oil extracts is an indication high proportion of minerals as reported by Ibok et al (2008) and Hassan et al., (2011). The \% crude protein obtained for $B$. aegyptiaca is closely similar to the value reported by Oderinde et al (2009) from Hura crepitans oil extracts (Figure 2). Arora and Tak (2013), reported a range of 26.0-26.8\% from Balanites roxburghii oil extract. The high protein constituent of the oil provides a good source of protein supplement in both human and animal diets (Hassan et al., 2011). B. aegyptiaca oil extract has more \% crude fiber than H. crepitans $(12.75>6.70 \%)$. This suggests its use as ingredient for animal feeds (Oderinde et al., 2009). The oil showed a very low content of carbohydrate compared to $H$. crepitans. This high carbohydrate content and crude fiber suggests the suitability of compounding the latter in animal feed, while the former could reduce the risk of coronary heart diseases, hypertension and breast cancer and diabetes.

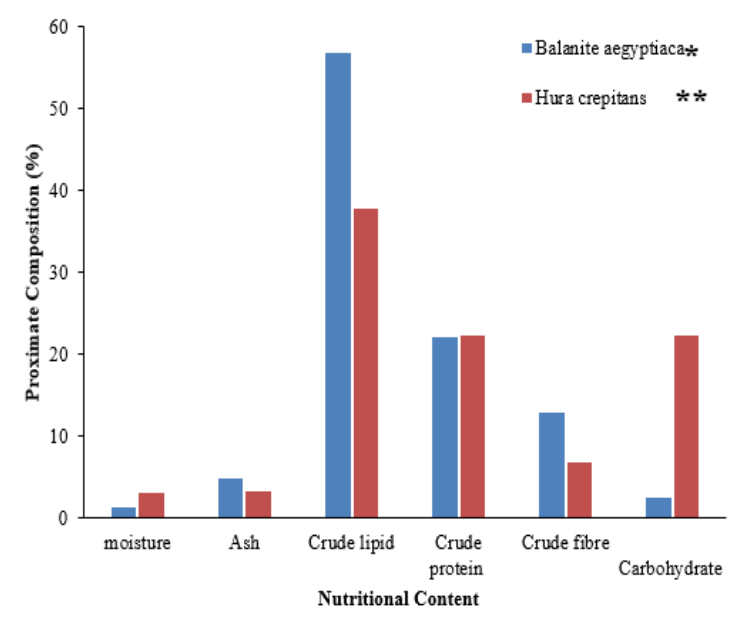

Fig 2: Nutritional analysis of Balanites aegyptical and Canariums schweinfurthii cake*(Present study) ** (Oderinde et al., 2009)

Biochemical composition and Biodiesel Properties of Balanites aegyptiaca: The average biochemical composition Balanites aegyptiaca revealed that the crude kernel oil had $0.949 \mathrm{~g} / \mathrm{cm}^{3}, 216.4 \mathrm{mg} \mathrm{KOH} / \mathrm{g}$ and $2.18 \mathrm{mgKOH} / \mathrm{g}$ as relative density, saponification and acid values respectively. While the peroxide, iodine and viscosity values were $4.84(\mathrm{meq} / \mathrm{Kg}), 77.08 \mathrm{~g} / 100 \mathrm{~g}$ and $150.3 \mathrm{~mm}^{2} / \mathrm{s}$ respectively. The crude kernel oil gave Light yellow Colour at room temperature and a non-drying oil class due to its iodine value( 77.08 $\mathrm{g} / 100 \mathrm{~g}$ ) (Figure 2). The cetane number and refractive index determined were 54.18 and 1.487(@30 $\left.{ }^{\circ} \mathrm{C}\right)$, while the calorific value was $39.031 \mathrm{MJ} / \mathrm{kg}$ (Figure 2). The relative density of the $B$. aegyptiaca oil extract $\left(0.949 \mathrm{~g} / \mathrm{cm}^{3}\right)$ compared favourably with $0.950 \mathrm{~g} / \mathrm{cm}^{3}$ 
of esterified B. aegyptiaca (Jauro and Adams., 2011), $0.903 \mathrm{~g} / \mathrm{cm}^{3}$ and $1.46 \mathrm{~g} / \mathrm{cm}^{3}$ of non-esterified Jatropha curcas (Umaru and Aberuagba, 2012) and Hura crepitans (Ottih et al., 2015). This figure was also relative to the limit of $0.96 \mathrm{~g} / \mathrm{cm}^{3}$ reported for
Automation Gas Oil (AGO) (Igbum et al., 2013), and the range ASTM standard $\left(0.875-0.900 \mathrm{~g} / \mathrm{cm}^{3}\right)$ and EN14214(0.86 - $\left.0.900 \mathrm{~g} / \mathrm{cm}^{3}\right)$, as reported by Odjobo and Umar (2019), showing good potential for biodiesel.

\begin{tabular}{|c|c|c|c|c|c|}
\hline Parameter & $\begin{array}{l}\text { *Balanites } \\
\text { aegyptiaca }\end{array}$ & $\begin{array}{l}\text { Jatropha } \\
\text { curcas }^{1}\end{array}$ & $\begin{array}{l}\text { Balanites } \\
\text { aegyptiaca }^{2}\end{array}$ & $\begin{array}{l}\text { Hura. } \\
\text { crepitans }^{3}\end{array}$ & Reference $^{4}$ \\
\hline Relative density $\left(\mathrm{g} / \mathrm{cm}^{3}\right)$ & $0.949^{\mathrm{a}}$ & 0.903 & 0.95 & 1.46 & $0.86-0.90\left(\mathrm{~g} / \mathrm{cm}^{3}\right)(\mathrm{EN}$ rec $)$ \\
\hline Refractive index $\left(@ 30^{\circ} \mathrm{C}\right)$ & $1.487^{\mathrm{a}}$ & 1.466 & 1.463 & 1.36 & \\
\hline Saponification value $(\mathrm{mgKOH} / \mathrm{g})$ & $216.43^{b}$ & 190.0 & 134.6 & 220.19 & \\
\hline Peroxide value(meq) & $4.84^{\mathrm{c}}$ & 2.0 & 8.0 & 20.00 & \\
\hline Acid value $(\mathrm{mgKOH} / \mathrm{g})$ & $2.18^{\mathrm{a}}$ & 36.2 & 0.995 & 7.09 & $0.60(\mathrm{EN}$ rec $)$ \\
\hline Iodine value $(\mathrm{g} / 100 \mathrm{~g})$ & 77.08 & 105.0 & 42.28 & 149.6 & $120(\mathrm{~g} / 100 \mathrm{~g})(\mathrm{EN} \mathrm{rec})$ \\
\hline Viscosity value (@30C) & 150.3 & 40.0 & 34.42 & 5.91 & \\
\hline Cetane number & 54.18 & & & & $51(\mathrm{EN} \mathrm{rec})$ \\
\hline Calorific value(MJ/kg) & 39.031 & & & & \\
\hline Colour & Light yellow & & & & \\
\hline Oil class & Non-drying & & & & \\
\hline
\end{tabular}

The refractive index of $1.487\left(@ 30^{\circ} \mathrm{C}\right)$ recorded from crude oil extract of $B$. aegyptiaca oil was close to 1.36 , 1.466 and 1.471 observed for Hura crepitans (Ottih et al., 2015), Jatropha curcas (Umaru and Aberuagba, 2012). Manji, et al. (2013), indicated a refractive index (RI) value of 1.478 from non - esterified oil extract of $B$. aegyptiaca. These findings thus suggested the oil from these seeds as potential bio diesel resources. According to Oderinde et al (2009), the refractive index describes the ratio of the velocity of light in vacuum to the velocity of light in a medium. It indicates the level of saturation of the oil as well as loss of unsaturation. The RI reduces with reduction in double bond (unsaturation). Japir et al (2017), pointed that high refractive index of oils is attributable to the high number of carbon atoms in their fatty acid composition.Acid values (AV) of $2.18 \mathrm{mgKOH} / \mathrm{g}$ obtained for non-esterified oil extract of B. aegyptiaca was higher than $0.995 \mathrm{mg} \mathrm{KOH} / \mathrm{g}$ reported from esterified study by (Jauro and Adams (2011). Other workers reported $7.09 \mathrm{mg} \mathrm{KOH} / \mathrm{g}$ and $36.2 \mathrm{mg}$ $\mathrm{KOH} / \mathrm{g}$ AVs for non-esterified crude oils of $H$. crepitans (Ottih et al 2015) and J curcas (Umaru and Aberuagba (2012). According to Ejilah, et al. (2012), the acid value indicates the extent of decomposition of the constituent glycerides by lipase activities. The acid value of the oil determines its, edibility, shelf life as well as industrial applications. Low AV oils $(<4.0 \mathrm{mg}$ $\mathrm{KOH} / \mathrm{g}$ ) (Nwe et al., 2019), are edible to human and livestock, stable over a long period of time and protect against rancidity (long shelf life) (Sunmonu et al., 2017). High AV value renders the oil inedible, but useful for production of paints, liquid soap and shampoos (Aremu et al., 2006a). Very low acid value is an indication of a good biodiesel potential (Umaru and Aberuagba, 2012). The peroxide value (PV) of oils $4.84 \mathrm{meq} / \mathrm{Kg}$ was obtained for non-esterified oil extract of B. aegyptiaca. $2.0 \mathrm{meq} / \mathrm{Kg}$ and $20.0 \mathrm{meq} / \mathrm{Kg}$ were reported for Jatropha curcas (Umaru and Aberuagba, 2012) and Hura crepitans (Ottih et al., 2015), while Jauro and Adams (2011) indicated a PV of $8.0 \mathrm{meq} / \mathrm{Kg}$ from esterified Balanites aegyptiaca oil extract. Manji et al. (2013), observed that a low PV indicated oil stability against oxidative degradation. They further remarked that rancidity commences when the peroxide value reaches $20-40 \mathrm{meq} / \mathrm{kg}$ (Charles and Guy, 1991). This has been viewed to result in polymerization of the esters and the formation of the gums and sediments, which clog the filters of the engines (Clark et al., 1984; Montcho et al., 2018). The iodine value (IV) of $77.08 \mathrm{~g} / 100 \mathrm{~g}$ of crude oils extract of $B$. aegyptiaca was higher than 42.28 $\mathrm{g} / 100 \mathrm{~g}$ reported for esterified sample by Jauro and Adams (2011). However, higher values (105.0 g/100g and $149.6 \mathrm{~g} / 100 \mathrm{~g}$ ) were obtained from non-esterified oils of Jatropha curcas (Umaru and Aberuagba, 2012) and $H$. crepitans (Ottih et al., 2015). According to Jauro and Adams (2011), oil classification is based on its iodine value (IV). Thus IV of $<100 \mathrm{~g} / 100 \mathrm{~g}$, between 100-130 g/100g and > $130 \mathrm{~g} / 100 \mathrm{~g}$ are considered non-drying, drying and semi-drying respectively. Consequently, the IV (77.08 g/100g) of the test crude oil of $B$. aegyptiaca renders the oil a nondrying. Higher IV also implies higher propensity for rancidity by oxidation (Ouilly et al., 2017). The low iodine value of the oil is highly advantageous because the oil would be stable to polymerization and/or oxidation. The lower IV authenticates seed oils for biodiesel production (Nwe et al 2019). The saponification value (SV) of $216.43 \mathrm{mgKOH} / \mathrm{g}$ obtained from crude oil extract of $B$. aegyptiaca oil compares favorably with $220.19 \mathrm{mg} \mathrm{KOH} / \mathrm{g}$ and 190.0 $\mathrm{mg} \mathrm{KOH} / \mathrm{g}$ from non-esterified oil extracts of Hura crepitans (Ottih et al 2015) and Jatropha curcas 
(Umaru and Aberuagba, 2012) respectively. However, esterified oil extract of $B$. aegyptiaca gave a relatively lower SV $134.6 \mathrm{mg} \mathrm{KOH/g} \mathrm{(B.} \mathrm{aegyptiaca} \mathrm{(Jauro} \mathrm{and}$ Adams (2011). According to Ejilah et al. (2012), The SV provides an index of the average molecular mass of fatty acids present in seed oil. The higher SV implies higher of molecular mass fatty acids. Oil extracts ranging from 130 to $193 \mathrm{mg} \mathrm{KOH} / \mathrm{g}$ (Jauro and Adams, 2011), 210-213 mg KOH/g (Nwe et al., 2019), 220.19mgKOH/g (Ottih et al (2015), etc, were considered suitable for use in biodiesel production. This is because higher saponification had been thought to improve the lubrication property of the oil, reduces engine wear, extend the operational life and efficiency of diesel fuel pumps and injectors (Ejilah et al 2012). In their opinion, Ottih et al (2015), suggested that oils with saponifaction value of $220.18 \mathrm{mg} \mathrm{KOH} / \mathrm{g}$ could be good for soap making, paint driers and production of shaving cream. (Mater, 2012). The viscosity values (VV) of the crude oil extracts of B. aegyptiaca of 150.3 $\mathrm{mm}^{2} / \mathrm{s}$ was higher than values of $5.91 \mathrm{~mm}^{2} / \mathrm{s}(H$. crepitans), $34.42 \mathrm{~mm}^{2} / \mathrm{s}$ (esterified B. aegyptiaca) and $40.0 \mathrm{~mm}^{2} / \mathrm{s}$ (non-esterified Jatropha curcas), reported by Ottih et al (2015), Jauro and Adams (2011) and Umaru and Aberuagba (2012) respectively. Meher et al. (2006), opined that viscosity reflects the operation of fuel injection from the diesel injector, flow in fuel pumps, and pipelines especially at low temperatures. Azuaga et al (2018), affirmed that viscosity of oil extracts depends on the nature of the constituent triglycerides, as well as their chemical properties. They explained that the oil viscosity and density increase and decrease respectively, with saturation unsaturation polymerictriglyceride chains. Viscosity also depends on sheer stress and temperature. Sheer stress does not have much effect on the storage of oils which are used for edible purposes but the temperature does affect it.

Fatty acids composition of crude kernel oil extract of $B$ aegyptiaca: The analysis of fatty acids composition of crude kernel oil extract of $B$ aegyptiaca revealed the presence Pentadecanoic acid $\left(\mathrm{C}_{17} \mathrm{H}_{34} \mathrm{O}_{2}\right)$, 9,12Octadecanoic acid $\left(\mathrm{C}_{19} \mathrm{H}_{34} \mathrm{O}_{2}\right)$, Heptacosanoic acid $\left(\mathrm{C}_{28} \mathrm{H}_{56} \mathrm{O}_{2}\right)$ and Oleic $\operatorname{acid}\left(\mathrm{C}_{18} \mathrm{H}_{34} \mathrm{O}_{2}\right)($ table 3$)$. The relative percentage abundance (RPA) of these fatty acids were in the order of $67.17 \%(9,12$-Octadecanoic acid $\left.\left(\mathrm{C}_{19} \mathrm{H}_{34} \mathrm{O}_{2}\right)\right)>16.22 \%$ (Pentadecanoic acid $\left.\left(\mathrm{C}_{17} \mathrm{H}_{34} \mathrm{O}_{2}\right)\right)>11.89 \%$ (Heptacosanoic acid $\left.\left(\mathrm{C}_{28} \mathrm{H}_{56} \mathrm{O}_{2}\right)\right)$ $>4.72 \%\left(\right.$ Oleic $\left.\operatorname{acid}\left(\mathrm{C}_{18} \mathrm{H}_{34} \mathrm{O}_{2}\right)\right)($ Table 3$)$.

\begin{tabular}{llllll}
\multicolumn{6}{c}{ Table 2: Fatty Acid Composition of Balanites aegyptiaca Seed oil Extracts } \\
\hline S/N & $\begin{array}{l}\text { Retention } \\
\text { Time (RT) min }\end{array}$ & Compound & formula & $\begin{array}{l}\text { HIT } \\
\text { Quality (\%) }\end{array}$ & $\begin{array}{l}\text { Percentage } \\
\text { composition }\end{array}$ \\
\hline 1 & 18.78 & $\begin{array}{l}\text { Pentadecanoic acid, 14- } \\
\text { methyl methyl ester }\end{array}$ & $\mathrm{C}_{17} \mathrm{H}_{34} \mathrm{O}_{2}$ & 92 & 16.22 \\
2 & 20.49 & $\begin{array}{l}\text { 9,12-Octadecanoic acid, } \\
\text { methyl ester (E,E) }\end{array}$ & $\mathrm{C}_{19} \mathrm{H}_{34} \mathrm{O}_{2}$ & 93 & 67.17 \\
3 & 20.69 & $\begin{array}{l}\text { Heptacosanoic acid, } \\
\text { methyl ester }\end{array}$ & $\mathrm{C}_{28} \mathrm{H}_{56} \mathrm{O}_{2}$ & 91 & 11.89 \\
4 & 21.17 & $\begin{array}{l}\text { Oleic acid } \\
\text { Four compounds }\end{array}$ & $\mathrm{C}_{18} \mathrm{H}_{34} \mathrm{O}_{2}$ & 90 & 4.72 \\
& & (Total) & 100 \\
\hline
\end{tabular}

The cetane number obtained showed a higher value (54.18) than the minimum recommended standard value (EN 14214) of 51.00(Sidohounde et al, 2019).Many workers have recorded relative values of cetane number $(\mathrm{CN})$ based on the different oils from different origin. $\mathrm{CN}$ of $44.53,47.80$, and 52.85 are obtained from seed oils of Hura crepitans (Sidohounde et al., 2019).Sclerocarya birrea (Marula) (Ejilah et al., 2012) and Ceiba pentandra (Montcho et al., 2018). According to Montcho et al. (2018), the cetane index measures a fuel ability to ignite itself (Aligrot, 1994). The higher the cetane number, the shorter the ignition delay time and the better the combustion quality (Haidara et al., 1996). The cetane index of Balanites aegyptiaca is 54.18(Table 2). This value was close to range of $40.0-55.0$ of petrol diesel recommended by ASTM D975 (Sidohounde et al., 2018). According to Demirbas (2006), longer chain fatty acids with more saturated molecules are more likely to produce higher cetane numbers and higher combustion efficiency (Ejilah, 2012). According to Sidohounde et al. (2018), some properties of oil (viscosity, oxidation stability, cetane number, etc), affect the fatty acids composition of extracted crude oil. Unsaturated fatty acids content of confers stability and durabilityto the oil. Highly unsaturated oil and the length of the $\mathrm{C}$ - $\mathrm{C}$ chain could reduce the cetane number of its biodiesel (Sidohounde et al., 2018).

Conclusion: The study revealed the crude oil extract of Balanites aegyptiaca to give high crude protein $(22.09 \%)$ and crude fat $(56.75 \%)$, saponification value (216.43 mg KOH/g), peroxide value (4.84 meq/Kg), acid value $(2.18 \mathrm{mg} \mathrm{KOH} / \mathrm{g})$, iodine value $(77.08 \mathrm{~g} / 100 \mathrm{~g})$, viscosity value $\left(150.3 \mathrm{~mm}^{2} / \mathrm{s}\right)$, cetane number (54.08), and calorific value $(39.03 \mathrm{MJ} / \mathrm{kg}$. Fatty acids assayed were in the order of $67.17 \%(9,12-$ Octadecanoic acid, $\left.\mathrm{C}_{19} \quad \mathrm{H}_{34} \mathrm{O}_{2}\right)>16.22 \%$ (Pentadecanoic acid, $\mathrm{C}_{17} \mathrm{H}_{34} \mathrm{O}_{2}$ ) $>11.89 \%$ 
(Heptacosanoic acid, $\mathrm{C}_{28} \mathrm{H}_{56} \mathrm{O}_{2}$ ) $>4.72 \%$ ( Oleic acid, $\mathrm{C}_{18} \mathrm{H}_{34} \mathrm{O}_{2}$ ).

\section{REFERENCES}

Adewuyi, A; Awolade, PO; Oderinde, RA (2014). Hura crepitans Seed Oil: An Alternative Feedstock for Biodiesel Production. J.Fuels. 1-8.

Al-Futuh, A (1989). Study on the processing of Balanites aegyptiaca fruits for food, drug and feed industry. Chapman and Hall, London. pp. 272278.

AOAC, (1997). Official Methods of Analysis of the Association of Official Analytical Chemists. $17^{\text {th }}$ edition, Washington DC, USA: Chapman and Hall Publisher.

Aremu, MO; Olaofe, O; Akintayo, ET (2006a). Chemical composition and physicochemical characteristics of two varieties of bambara groundnut (Vigna subterrenea) flours. J. Appl. Sci. 6(9): $1900-1903$.

Azuaga, IC; Igbum, GO; Kyenge, BA (2018). Extraction and Characterization of Three Tropical Seedoils: Telfairia occidentalis, Hura crepitans and Cucumeropsis mannii. Chem. Res. J. 3(6):18.

Babatunde, OA; Bello, GS (2016). Comparative assessment of some Physicochemical Properties of Groundnut and Palm Oils Sold Within Kaduna Metropolis, Nigeria. IOSR J. Appl. Chem. 9 (11): 2278-5736.

Banik, SK; Rouf, MA; Rabeya, T; Khanam, M; Sajal, SI; Sabur, SB; Islam, MR (2018). Production of biodiesel from neem seed oil. Bangl. J. Sci. Ind. Res. 53(3): 211-218.

Batel, W; Graef, M; Meyer, GJ; Moller, R; Schoedder, F (1980). "Pflonzenole fur die Kraftstoff-und Energieversorgung," Grundlagen der Landtechnik. 30: 40-51.

Charles, A; Guy, L (1991). Food Biochemistry. Llis Howard Ltd., Market Cross-House, Cooper Street Chichester, West Sussex Po/9/EB, England, pp. 89-92.

Demirbas, A (2006). Biodiesel production via noncatalytic SCF method and biodiesel fuel characteristics. Ener. Conver. Manage. 47: 22712282.
Ejilah, R; Lukman, A; Bello, A (2012). Review of Sclerocarya birrea seed oil extracted as a bioenergy resource for compression ignition engines. Int. J. Agric. Biol. Eng. 5(3): 1-9.

Gutti, B; Bamidele, SS; Bugaje, IM (2012). Biodiesel Kinematics Viscosity Analysis of Balanite aegyptiaca seed oil. ARPN J. Eng. Appl. Sci. 7(4): 432-435.

Igbum, OG; Eloka-Eboka, AC; Nwadinigwe, CA (2012). Effects of Transesterification Variables on Yields and Properties of Biodiesel Fuels Produced from Four Virgin Tropical Seeds Oils. Int. J. Environ. Bioener. 1(2): 119-130.

Jain, S; Sharma, MP (2014). Effects of metal contents on oxidation stability of biodiesel/diesel blends. Fuel. 116:14.

Japir, AAW; Salimon, J; Derawi, D; Bahadi, M; AlShuja'a, S; Yusop, MR (2017). Physicochemical characteristics of high free fatty acid crude palm oil. OCL: Oilseeds. fats, Crops Lipids. 24(5): 1-9.

Jauro, A; Adams, M H (2011). Production and Biodegradability of Biodiesel from Balanites Aegyptiaca Seed Oil. J.Kor. Chem. Soc. 55 (4): 680-684.

Krisnangkura, K (1986). "A simple method for estimation of Cetane index of vegetable oil methyl esters," JAOCS: J. Amer. Oil Chem. Soc. 63(4): 552-553.

Lele, S (2009). Biodiesel in India. Publication of Indian Biodiesel Awareness Centre. http://www.svlele.com. Viewed on:2/05/2009.

Manji, AJ; Sarah, EE; Modibbo, UU (2013). Studies on the potentials of Balanites aegyptiaca seed oil as raw material for the production of liquid cleansing agents. Int. J. Phys. Sci. 8(33): 16551660.

Meher, LC; Vidya, SD; Naik, SN (2006). Technical aspects of biodiesel production by transesterification-a review. Renew. Sust. Ener. Rev. 10 (3): 248-268.

Mlambo, V; Dlamini, BJ; Ngwenya, MD; Mhazo, N; Beyene, ST; Sikosana, JLN (2011). In sacco and in vivo evaluation of marula (Sclerocarya birrea) 
seed cake as a protein source in commercial cattle fattening diets. Lives. Res. Rural Dev. 23 (5):1-10

Montcho, P; Tchiakpe, L; Nonviho, G; Bothon, FTD; Sidohounde, A et al. (2018). Fatty acid profile and quality parameters of Ceiba pentandra (L.) seed oil: A potential source of biodiesel. J. Petrol. Technol. Alter. Fuels. 9(3): 14-19.

Nwe, WH; Sotanaphun, U; Narakornwit, W; Sittisombut, C; Wetwitayaklung, P (2019). Physicochemical characters and fatty acid composition of Payena lucida seed oils. Thai. J.Pharm.Sci. 43(2): 76-82.

Oderinde, RA; Ajayi, IAA; Adewuyi, A (2009). Characterization of Seed and Seed Oil of Hura crepitans and The Kinetics of Degradation of the Oil during Heating. Electronic J. Environ. Agric. Food Chem. 8(3): 201-208

Odjobo, BO; Umar, A (2019). "Investigation of biodiesel fuel potential of Canarium Schweinfurthii Seed and Pulp Oils." Int. J. Engine. Sci. (IJES). 8(12): 58-61.

Ottih, OP; Aneke, NAG; Ejikeme, PC (2015). Production and Characterization of Paint Driers from Sand Box Seed Oil (Hura crepitans). Int. J. Inno. Sci. Engine. Technol. 2(2):71-76.

Ouilly, JT; Bazongo, P; Bougma, A; Kaboré, N; Lykke, AM; Ouédraogo, A et al. (2017) Chemical composition, physicochemical characteristics, and nutritional value of Lannea kerstingii seeds and seed oil. J. Anal. Mtds. Chem.1-6: 13.

Pa Qurt, C (1979). IUPAC standard methods for the analysis of oils, fats and derivatives. Pergamon Press. Oxford. pp. 16-162.

Pearson, D (1981). The chemical analysis of foods. 7th Ed. Churchill Livingstone, Edinburgh. pp 504530 .
Rizvi, SQA (2009). A comprehensive review of lubricant chemistry, technology, selection, and design. Copyright Edition, ASTM International Publication, Baltimore, USA. Pp.91- 597.

Sandulachi, E; Bulgaru, V; Tatarov, P (2019). Study of the Light Influence on the Walnuts Oil Quality. Asian Food Sci.J. 10(1): 1-10.

Sidohounde, A; Agbangnan, DCP; Nonviho, G; Montcho, PS; Sohounhloue, CKD (2018). Biodiesel potentials of two phenotypes of Cyperus esculentus unconventional oils. $J$. Petrol.Technol.Alter. Fuels. 9(1):1-6.

Sidohounde, A; Nonviho, G; Bothon, FTD; Montcho, PS; Dossa, CPA; Tchiakpe, L; Sohounhloue, DCK (2019). Biodiesel Synthesis by Ethanolysis of Hura crepitans Seed Oil Unfit for Consumption in Benin. Amer. J. Phys. Chem. 8(3): 50-57.

Sreedhar, I; Yandapalli, KK (2016). Process standardization and kinetics of ethanol driven biodiesel production by transesterification of ricebran oil. Int. J. Ind. Chem. 7: 121.

Sunmonu, MO; Ajala, EO; Odewole, MM; Morrison, S; Alabi, AM (2017). Comparative Analysis of Physico-Chemical Properties of Oil Extract From two Varieties of Fluted Pumpkin Seeds Using Different Extraction Methods. Kathmandu Univ. J.Sci. Engine. Technol. 13(1): 48-60.

Umaru, M; Aberuagba, F (2012). Characteristics of a Typical Nigerian Jatropha curcas oil Seeds for Biodiesel Production, Res.J. Chem. Sci. 2(10): 7 12.

Yunus, MM; Zuru, AA (2017). Kinetics Study of Balanites Aegyptiaca Oil Transesterification for the Production of Biodiese. Nig. J. Chem. Res. 22(1): 9-19. 